\title{
A Characterization Study to Indetify Antibactrial Effect of Ruta Graveolens (Hurb of Grace)
}

Najim A. Jabir *, Bassam A. Al Safy, Ali Tahir

College of Pharmacy/Thi-Qar University, Iran.

*Corresponding Author: Najim A. Jabir, College of Pharmacy/Thi-Qar University, Iran.

Received date: November 12, 2021; Accepted date: December 13, 2021 ; Published date: January 06,2022

Citation: Najim A. Jabir, Bassam A. Al safy, Ali Tahir (2022) A Characterization Study to Indetify Antibactrial Effect of Ruta Graveolens (Hurb of Grace).. Pharmaceutics and Pharmacology Research, 5(2); DOI:10.31579/2693-7247/048

Copyright: (C) 2022 Najim A. Jabir, This is an open access article distributed under the Creative Commons Attribution License, which permits unrestricted use, distribution, and reproduction in any medium, provided the original work is properly cited.

Summary
Most of rural people even today depend on plants for medicines. The use of complentary and alternative medicine (CAM)
has become increasingly popular worldwide, such that an estimated 38\% of American adults reported using a form of
CAM in 2006. The study of herbal remedies is common because many diseases and infections are known to have been
treated with natural medicinal plants throughout the history of humanity.
Ruta graveolens is aromatic shrub belong to family rutaceae and is commonly known as rue, cultivated as ornamental and
medicinal herb in gardens. Due to its cultural and medicinal value, rue has been introduced in various countries of North,
Central and South America, China, India, Middle East and South Africa. This plant also contains glucoside rutin. The
flavonoids are a part of primary chemical components of Ruta graveolens Linn. The most important analyzed flavonoids
are rutin (quercetin-3- $\beta$ - rutinoside) that belongs to flavonol glycoside. Quercetin is other major flavonoids found in Ruta
graveolens and can also be obtained by rutin hydrolysis.
Key words: ruta graveolens ; anti bacterial; diffusion disk

Introduction

Medicinal plant components still play very important role in the treatment of many infectious diseases and primary health care in many occidental countries. The plant based chemical compounds are classified into two classes [1-3]:

A. Primary and

B. Secondary metabolites based on their chemical, biosynthetic origin and functional groups.

Primary metabolites are involved in growth and development and secondary metabolites are involved in defense mechanism against harmful pests and infectious agents. The latter class exhibit medicinal properties. Plant derived chemicals such as terpenoids, phenolics, alkaloids, flavonoids, glycosoids, diterpenes, tri terpenes and minor chemicals are having better compatibility with human body.

It is estimated that $30 \%$ of the worldwide sales of drugs are based on plants products. The increasing antibiotics resistant by any pathogens and failure of many chemotherapeutics has led the screening of medicinal plants for their antimicrobial activity. The existence of saponin, tannins and glycosides has also been proven. The main active compound of Ruta graveolens are flavonoid and glycosides, and the structure of Ruta graveleons analogs:<smiles>Cn1c(-c2ccc3c(c2)OCO3)cc(=O)c2ccccc21</smiles>

Graveoline

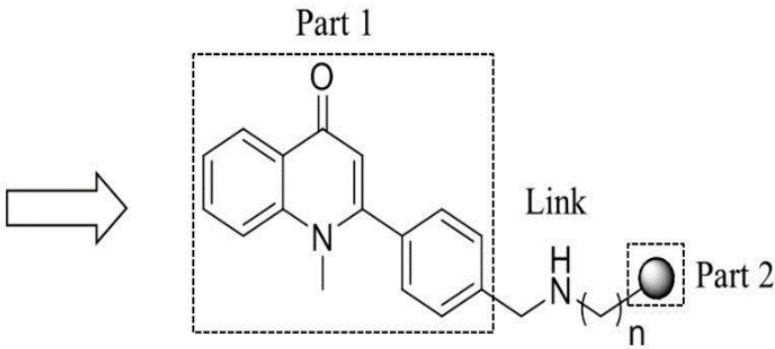

Graveoline analogs

Figure -1. Formation of Graveoline analogs 
Decoction of ruta graveolens is used to promote menstruation. Plant contains various volatile compound and oils. Fresh leaves used to relieve headache. In homeopathy this plant is used for the treatment of muscular pain, injuries, sprains, eye strain, joint and bone pain, arthritis, rheumatism, tennis elbow, back and head ache. Al awwadi N.J. et al, (2004) improved that the plants extract rich flavonoides have antihyper trophy cardiac and lowering blood pressure.

Infectious diseases are the leading cause of global morbidity and mortality. In 1990, infections cause 16 million deaths, and in 2010, the number of deaths had fallen to 15 million. The spread of infectious diseases results as much from changes in human behavior--including lifestyles and land use patterns, increased trade and travel, and inappropriate use of antibiotic drugs--as from mutations in pathogens. Staphylococcus aureus and Escherichia coli are a major cause of various humans and animals infections. The first causes skin and soft ugh the numbers of the different $\mathrm{E}$. coli $\mathrm{O}, \mathrm{K}$, and $\mathrm{H}$ antigens tissues infections, surgical site infections, and bone and joint infections. Staphylococcus aureus is a common cause of hospital-acquired bacteremia and it is associated with hospital-acquired respiratory tract infections.

E. coli is the most common cause of urinary tract infections (UTIs) in humans, and is a leading cause of enteric infections and systemic infections. The systemic infections include bacteremia, nosocomial pneumonia, cholecystitis, cholangitis, peritonitis, cellulitis, osteomyelitis, and infectious arthritis. E. coli is also leading cause of neonatal meningitis. A wide range of antimicrobial agents effectively inhibit the growth of E. coli. The lactams, fluoroquinolones, aminoglycosides and trimethoprim-sulfamethoxazole are often used to treat community and hospital infections due to E. coli, but antimicrobial resistant isolates, especially those that are fluoroquinolone resistant and those producing extended-spectrum -lactamases have increased significantly during the 2000's and in certain areas many nosocomial and community-acquired E. coli are now resistant the several important antimicrobial classes.

Antibiotic resistant staphylococci are major public health concern since the bacteria can be easily circulated in the environment. Infections due to methicillin-resistant Staphylococcus aureus (MRSA) have increased worldwide during the past twenty years. However significant reports are available about the antimicrobial activity of Ruta graveolens; therefore, activities of stem extraxt of Ruta graveolens using Staphyiococcus aureus and Escherichia coli and isolate glycoside and flavonoids from Ruta graveolens extract and examine antibacterial activity and compare result with antibiotics drug that frequently used for treatment of infection caused by this bacteria $[6,8,11-22]$.

\section{Material and Methods}

Chemical Study : Ruta graveolens flowers were purchased from the local market of Nasiriya and grounded to a powder then kept in dry container.

The ethanolic extract was prepared by mixing $50 \mathrm{gm}$ of Ruta graveolens powder with $200 \mathrm{ml}$ of $70 \%$ ethanol. Then the extraction process done by Soxhlet extractor condenser for 5 hours. This mixture was filtered by filter paper and then cooled. The filtrate was dried and concentrated using rotary evaporator at $50^{\circ} \mathrm{C}$. Water based Ruta graveolens extract was prepared in the same way except that distilled water was used instead of alcohol.

Steps :

- Maceration 50 gm.of the powdered leaves in $500 \mathrm{ml}$ of petroleum ether for $24 \mathrm{hr}$. or overnight. (Prepared previously)

- The residue was dried

- Soxhlet again with $70 \%$ aqueous ethanol

- Filter

- Concentrated the extracted to small volume

- Add $5 \mathrm{ml}$ of $5 \% \mathrm{HCL}$

- Boil for 2 min.

- Cool \& transfer to a separators funnel

- Shake with $15 \mathrm{ml}$ of chloroform to give

Aqueous layer Fraction B \& chloroform layerFraction A

A. Fraction A: Contain the aglycone part (flavonoid).

B. Fraction B : Contain the glycone part

Stock solution preparation: The stock solution of flavonoid extract done by dissolving $1 \mathrm{gm}$ of the extract in $10 \mathrm{ml}$ of ethanol to get a concentration of $100 \mathrm{mg} / \mathrm{ml}$ which was the highest concentration tested. Sterilization was done by filtration wares through a Millipore $0.45 \mathrm{~mm}$ and $0.22 \mathrm{~mm}$. The concentration tested were $(100,200,400) \mathrm{mg} / \mathrm{ml}$.

\begin{tabular}{|l|l|l|l|l|}
\hline Code No & Chemical structure & Chemical test & Test result & Chemical note \\
\hline 1 & Glycoside & Benedict & $+\mathrm{Ve}$ & Formation of red precipitate \\
\hline 2 & Tannin & Fecl3 & $+\mathrm{Ve}$ & $\begin{array}{l}\text { Formation of bluish green } \\
\text { color }\end{array}$ \\
\hline 3 & Saponin & Shaken of the extraction & $-\mathrm{Ve}$ & No formation of foam \\
\hline 4 & flavonoids & Alcohol KOH & $+\mathrm{Ve}$ & $\begin{array}{l}\text { Formation of yellow } \\
\text { precipitate }\end{array}$ \\
\hline 5 & Coumarin & Filter paper soaked by diluted NaoH & $-\mathrm{Ve}$ & $\begin{array}{l}\text { No formation of yellowish } \\
\text { green color on filter paper }\end{array}$ \\
\hline 6 & Terpenoids & $\begin{array}{l}\text { Liebermann burchard chloroform } \\
+ \text { A.A.A+ H2SO4 }\end{array}$ & $+\mathrm{Ve}$ & $\begin{array}{l}\text { Formation of pale brown } \\
\text { color }\end{array}$ \\
\hline 7 & Liebermann burchard & $+\mathrm{Ve}$ & Formation of green color \\
\hline 8 & Steroids & Ethanol 95\% +boiling + 4\% HCL & $-\mathrm{Ve}$ & $\begin{array}{l}\text { No formation of turbidity } \\
\text { pormation } \\
\text { precipitate }\end{array}$ \\
\hline 10 & Alkaloids & Dragendroff reagent & Formation of violet ring \\
\hline 11 & Carbohydrate & Molish reagent & $\begin{array}{l}\text { Formation of bright pinkish } \\
\text { violet colour }\end{array}$ \\
\hline
\end{tabular}




\section{Anti-bacterial effect study}

The determination of anti-bacterial activity of the two extracts was by using of the agar gel diffusion technique. Muller- hinton agar plates with $0.1 \mathrm{ml}$ of overnight culture were used which was allowed to incubate for 24 hrs cup were made in petri plates using sterile corn borer $\{0.85 \mathrm{~cm}\}$ and $50 \mu 1$ of each extract was added into each well then the incubation of bacterial plate at $37^{\circ} \mathrm{c} 24 \mathrm{hrs}$.each test compound has two bores for which the diameter and mean values of inhibition zone were determine

\section{Result:}

In the first test, none of the discs in quantifies of alcoholic (ethanolic) extracts of Ruta graveolens inhibited the growth that showed no interdiction effect of extract with the values on the growth of Staphylococcus aureus and E.coli, In other words, all studied strains showed resistance to the extract in disc diffusion test (figure 1 and table1) and in serial concentration test up to $1 \mathrm{mg} / \mathrm{ml}$ concentration.

In the second test, disks containing alcoholic extract compared with antibiotics disks showed no effect on the growth of Staphylococcus aureus and E.coli, whereas the inhibitory effect of antibiotics on bacteria showed growth .In the third test was performed to determine the inhibitory effect of two secondary metabolite obtained from Ruta graveolens. outside and flavonoids) on the grow of Staph.

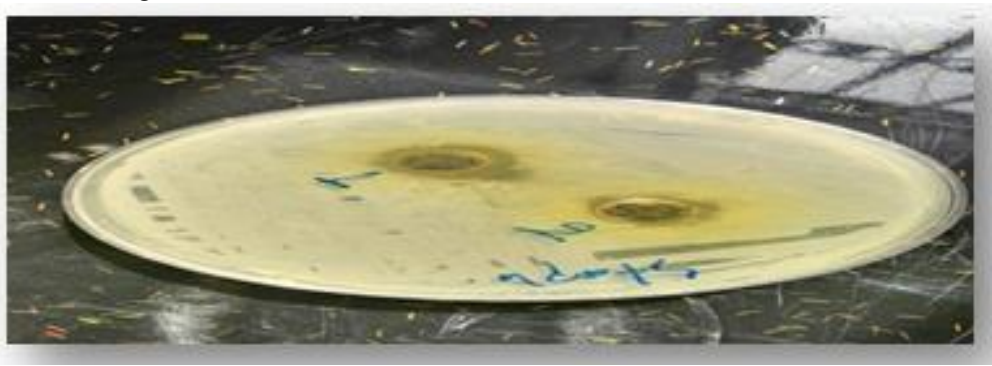

Figure 1: No inhibition zone on diffusion disk for Staphylococcus aureus bacteria

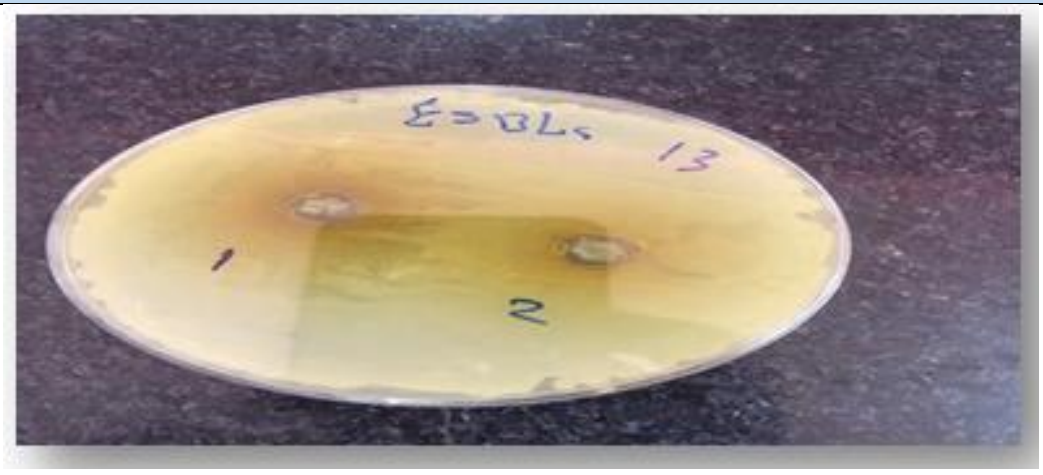

Figure 2: No inhibition zone on diffusion disk for E.coli

\section{Discussion}

Ruta graveolens is known medical plant since many years and having several medical. Antimicrobial effect of the plant is studied before. Oliva et al (2003) reported antifungal effect of Ruta graveolens leave in two different studies. Antiparasitic effect of Ruta graveolens is reported in study of PM Guarrera (1999) and antibacterial effect of the plant is studied several times. A. Ivanova, et al, (2005), found antibacterial effect of the plant on Staphylococcus aureus, Staphylococcus epidermidis, and bacillus subtilis. Study of Oliva et al (2003) showed antibacterial effect of the hydro-alcoholic extract of the plant on pseudomonas aeruginosa. In the study of Al zoreky NS (2009) and T. Ojala, et, al, (2000) the Ruta graveolens leaves showed antimicrobial effect against Staphylococcus aureus. In another study, phenolic component, alkaloids, and trepnoides extracted from ruta graveolens showed antimicrobial effect on Staphylococcus aureus and Bacillus subtilis. Al zoreky NS (2009) reported that extracts of this plant has more effect on gram positive bacteria than gram negative pathogens. In this study we found that alcoholic extract of ethanol $70 \%$ of this plant has no antibacterial effect on main human pathogens even those bacteria that reported which are sensitive in previous studies
Our finding are compatible with results of study of Saderi et al, (2006) showed that the ethanol extract of the Ruta graveolens has no inhibitory effect on staphylococcus aureus. The difference might be attributed to the type of extract. Al zoreky NS (2009) used methanol extract $(80 \%$ methanol with $20 \%$ PBS) and he found the MIC was $2.6 \mathrm{mg} / \mathrm{ml}$. In the study of T. Ojala, et al, (2000) that used methanol extract (pure methanol) MIC was lower $(0.126 \mathrm{mg} / \mathrm{ml})$. It seems that there might be more antibacterial components in methanol extract and also in leaves extract and in pure ethanol extract. Saderi et al, (2006), used hydro extract of leaves of the plant on Staph. Aureus and found that MIC was $10 \% \mathrm{v} / \mathrm{v}$ that is similar to ethanol (pure) extract of leaves on P. aeroginosa . These differences might be due to different resistance of the bacteria. In our study, most used strains showed multidrug resistance to the all the antimicrobial agents used in our study (results are not shown). We more study in this issue. The tested crude extract from Ruta graveolens have proved to be promising treating agents against the tested pathogenic microbes but it need to be more concentrated and furthermore.

\section{Conclusions}

The tested crude extract from Ruta graveolens have proved to be promising treating agents against the tested pathogenic microbes but it need to be concentrated and furthermore evaluated; hence more studies 
pertaining to the use of plants as therapeutic agents should be emphasized especially those related to the control of antibiotic resistance microbes.

\section{References}

1. Ghirardini Maria; Carli Marco; Del Vecchio, Nicola; Rovati, Ariele; Cova, Ottavia; et al. (2007). The importance of a taste. A comparative study on wild food plant consumption in twentyone local communities in Italy. Journal of Ethnobiology and Ethnomedicine.

2. Spencer Hornsey, Ian (December 2003). Chapter 3. A History of Beer and Brewing. Royal Society of Chemistry. p. 103. ISBN 978-0-854-04630-0.

3. Al-Zoreky NS. (2009) Antimicrobial activity of pomegranate (Punica granatum L.) fruit peels. (2009). Int J Food Microbiol. 15; 134(3):244-8.

4. Dempster, J.P. (1995) The ecology and conservation of Papilio machaon in Britain. In Pullin, Andrew S. Ecology and Conservation of Butterflies (1st ed.). London: Chapman \& Hall. pp. 137-149. ISBN 0412569701.

5. Arias-Santiago, SA; Fernández-Pugnaire, MA; AlmazánFernández, FM; Serrano-Falcón, C; Serrano-Ortega, S (2009) Phytophotodermatitis due to Ruta graveolens prescribed for fibromyalgia. Rheumatology (Oxford, England). 48 (11): 1401. doi:10.1093/rheumatology/kep234.

6. Furniss, D; Adams, T (2007) Herb of grace: An unusual cause of phytophotodermatitis mimicking burn injury. Journal of Burn Care \& Research. 28 (5): 767-769. doi:10.1097/BCR.0B013E318148CB82.

7. Eickhorst, K; Deleo, V; Csaposs, J (2007) Rue the herb: Ruta graveolens-associated phytophototoxicity. Dermatitis. 18 (1): 52-55. doi:10.2310/6620.2007.06033.

8. A Ivanova, B Mikhova, H Najdenski, I Tavetkova, I kostova, Fitoterapia (2005) Antimicrobial and cytotoxic activity of Ruta graveolens, Fitoterpia, 76; 344-347.

9. Wessner, D; Hofmann, H; Ring, J (1999) Phytophotodermatitis due to Ruta graveolens applied as protection against evil spells. Contact dermatitis. 41 (4): 232. doi:10.1111/j.16000536.1999.tb06145.x.
10. Rethy, Borbala; Zupko, Istvan; Minorics, Renata; Hohmann, Judit; Ocsovszki, Imre; Falkay, George (2007) Investigation of cytotoxic activity on human cancer cell lines of arborinine and furanoacridones isolated from Ruta graveolens. Planta Medica. 73 (1): 41-48. doi:10.1055/s-2006-951747.

11. Srivastava, S. D.; Srivastava, S. K.; Halwe, K. (1998) New coumarins and limonoids of Ruta graveolens. Fitoterapia. 69 (1): 7-12. INIST:2179664

12. Steck, Warren; Bailey, B.K.; Shyluk, J.P.; Gamborg, O.L. (1971) Coumarins and alkaloids from cell cultures of Ruta graveolens. Phytochemistry. 10: 191-194. doi:10.1016/S00319422(00)90269-3.

13. T Ojala, S Remes, P Haansuu, H Vuorela, R H aahtela, P Vuorela. (2000) Journal of Ethnopharmacology. 73,299-305.

14. Oliva, Anna; Meepagala, Kumudini M.; Wedge, David E.; et al. (2003) Natural Fungicides from Ruta graveolens L. Leaves, Including a New Quinolone Alkaloid. Journal of Agricultural and Food Chemistry. 51 (4): 890-896. doi:10.1021/ jf0259361.

15. Zobel, Alicja M.; Brown, Stewart A. (1988) Determination of Furanocoumarins on the Leaf Surface of Ruta graveolens with an Improved Extraction Technique. Journal of Natural Products. 51 (5): 941-946. doi:10.1021/np50059a021.

16. Kong, Y.; Lau, C.; Wat, K.; Ng, K.; But, P.; Cheng, K.; Waterman, P. (2007). Antifertility Principle of Ruta graveolens. Planta Medica. 55 (2): 176-8. doi:10.1055/s-2006-961917.

17. De Feo, Vincenzo; De Simone, Francesco; Senatore, Felice (2002) Potential allelochemicals from the essential oil of Ruta graveolens. Phytochemistry. $61 \quad$ (5): 573-578. doi:10.1016/s0031-9422(02)00284-4.

18. Saderi H, Olia P and Radmanesh M (2006) Antibacterial effect of hydro alcoholic and aqueous extract of seed and stem of Ruta graveolens on S. aureus ( In Persian ), Iran J, Med, Aroma, $22(4) ; 366-372$.

19. P Olia, H saderi, A Tabatabaeijejad, m Naseri, (2004) Reaserches on medical plants of Iran, 20(2), 171-180.

20. NS Alzorekry, k Nakahara. (2003) International Journal of Food Microbiology, 80,223-230.

21. Olia P and RadmaneshM (2006) Antibacterial effect of hydro alcoholic and aqueous extract of seed and stem of Ruta graveolens on S. aureus (In Persian), Iran J Med, Aroma, 22(4) ; 366-372.

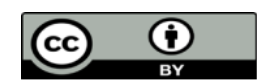

This work is licensed under Creative

Commons Attribution 4.0 License
Submit Manuscript
To Submit Your Article Click Here:

DOI: $10.31579 / 2688-7517 / 048$
Ready to submit your research? Choose Auctores and benefit from:

$>$ fast, convenient online submission

$>$ rigorous peer review by experienced research in your field

$>$ rapid publication on acceptance

$>$ authors retain copyrights

$>$ unique DOI for all articles

$>$ immediate, unrestricted online access

At Auctores, research is always in progress.

Learn more https://auctoresonline.org/journals/pharmaceutics-andpharmacology-research 